American Journal of Biochemistry and Biotechnology 5 (3): 98-108, 2009

ISSN 1553-3468

(C) 2009 Science Publications

\title{
Camel's Milk Protects against Aluminum Chloride-Induced Toxicity in the Liver and Kidney of White Albino Rats
}

\author{
Fahaid Al-Hashem \\ Department of Physiology, College of Medicine, \\ King Khalid University, Abha 61421, Saudi Arabia
}

\begin{abstract}
Problem statement: Aluminum chloride $\left(\mathrm{AlCl}_{3}\right)$ is commonly used in daily life but it can be potentially toxic. Therefore, the present study was carried out to investigate the protective effects of camel's milk against aluminum-induced biochemical alterations and oxidative stress in the liver and kidney of white albino rats. Approach: White albino male rats (230-250 g) were divided into three groups of 10 rats: a control group treated with normal saline, the $\mathrm{AlCl}_{3}$-treated group and the camel's milk- $\mathrm{AlCl}_{3}$-treated group. The $\mathrm{AlCl}_{3}$ treated group received $0.5 \mathrm{mg} \mathrm{kg}{ }^{-1}$ of $\mathrm{AlCl}_{3}$ orally. The camel's milk- $\mathrm{AlCl}_{3}$-treated group was fed $1 \mathrm{~mL}$ of fresh camel's milk 10 minutes prior to the administration of oral $\mathrm{AlCl}_{3}$. All rats were treated every day for 30 days. Liver and kidney biochemical serum parameters were analyzed. Lipid peroxidation, as determined by the tissue concentrations of thiobarbituric acid reactive substances (TBARS) and hydrogen peroxide (HP), and the oxidative stress status, as measured by glutathione (GSH), superoxide dismutase (SOD) and catalase (CAT) activity, were evaluated in the kidney and liver of treated rats. Results: Data showed that the oral administration of $\mathrm{AlCl}_{3}$ resulted in statistically significant increases in the serum levels of urea, creatinine, bilirubin, aspartate aminotransferase (AST), alanine aminotransferase (ALT), alkaline phosphatase (ALP), lactate dehydrogenase (LDH), cholesterol and triglycerides; the total amount of protein and albumin were also significantly decreased. However, these parameters were within normal levels in the rats given camel's milk prior to $\mathrm{AlCl}_{3}$. Additionally, oral administration of $\mathrm{AlCl}_{3}$ induced lipid peroxidation in the liver and kidney, which was indicated by a significant increase in lipid peroxidation biomarkers (TBARS and HP) and a significant decrease in the activities of GSH, SOD and CAT. In all rats treated with camel's milk before being given $\mathrm{AlCl}_{3}$, lipid peroxidation and oxidative stress parameters were within normal levels. Conclusion: Treatment with camel's milk prior to $\mathrm{AlCl}_{3}$ exposure alleviates $\mathrm{AlCl}_{3}$-associated hazards and protects the kidney and liver from $\mathrm{AlCl}_{3}$ toxicity.
\end{abstract}

Key words: Aluminum chloride, camel's milk, kidney, liver, rats, toxicity

\section{INTRODUCTION}

Aluminum, which is the most abundant metal and comprises about $8 \%$ of the Earth's crust, is found in combination with oxygen, silicon, fluorine and other elements in the soil, rocks, clays and gems ${ }^{[1]}$. It has no known biological function ${ }^{[2]}$. Presently, aluminum utensils are widely used throughout the world, especially in developing countries ${ }^{[3]}$. The use of such tools may increase an individual's aluminum exposure, particularly when these are used with salty, acidic or alkaline foods ${ }^{[4]}$.

Additionally, aluminum and its salts are commonly used in daily life as it was believed that it was non-toxic and was quickly excreted in the urine. However, this element can negatively impact human health ${ }^{[5]}$.
Aluminum chloride $\left(\mathrm{AlCl}_{3}\right)$ can be found in food products and in drinking water derived from both natural sources and treatment methods ${ }^{[6]}$. The primary sources of aluminum exposure are corn, yellow cheese, salt, herbs, spices, tea, cosmetics, cookware, utensils and containers. Furthermore, it is widely used in food additives and toothpaste ${ }^{[7]}$. Aluminum compounds are widely used in medicines, e.g., antacids, phosphate binders, buffered aspirins, vaccines and injectable allergens ${ }^{[8-10]}$. Environmental pollution with different aluminum-containing compounds, especially industrial waste water, exposes people to higher than normal levels of aluminum ${ }^{[11]}$. Particulate matter distributed by cement-producing factories contains a high amount of aluminum and populations residing near these facilities are exposed to this pollution ${ }^{[12]}$. 
Aluminum is potentially toxic to humans. The Agency for Toxic Substances and Disease Registry (ATSDR) ${ }^{[13]}$ reported that aluminum is distributed mainly in the bone, liver, testis, kidneys and brain. In patients on dialysis ${ }^{[14]}$ or on long-term total parenteral nutrition ${ }^{[15]}$, this metal accumulates in different organs. The toxicological effects of aluminum in humans include encephalopathy ${ }^{[14]}$, bone disease ${ }^{[16]}$, anemia ${ }^{[17]}$ and skeletal system disease ${ }^{[18]}$. Furthermore, aluminum is possibly a contributing factor in the development of Alzheimer's disease ${ }^{[19]}$. However, this remains contradictory ${ }^{[18,20]}$.

Camel's milk is different from other ruminant milk; it is low in cholesterol, sugar and protein but high in minerals (sodium, potassium, iron, copper, zinc and magnesium), vitamins $\mathrm{A}, \mathrm{B} 2, \mathrm{C}$ and $\mathrm{E}$, and contains a high concentration of insulin ${ }^{[21]}$. It has no allergic properties and can be consumed by lactase-deficient individuals and those with a weakened immune system.

In fact, this milk is believed to have medicinal properties. In Sahara, fresh butter made from camel's milk is often used as a base for medicines. Other products also developed with camel's milk include cosmetics or pharmaceuticals. A series of metabolic and autoimmune diseases are successfully being treated with camel's milk. Furthermore in India, camel's milk is used therapeutically to treat dropsy, jaundice, problems of the spleen, tuberculosis, asthma, anemia, piles and diabetes $^{[22]}$. A beneficial effect of raw camel's milk has been observed in chronic pulmonary tuberculosis patients ${ }^{[23]}$. Also, in repeated trials, a 30-35\% reduction in the daily insulin dose required by patients with type 1 diabetes was observed in response to treatment with raw camel's milk ${ }^{[24]}$.

To the best of our knowledge, the therapeutic effect of camel's milk against $\mathrm{AlCl}_{3}$-induced toxicity has not been examined. Therefore, in the current study, we evaluated the protective effects of camel's milk against $\mathrm{AlCl}_{3}$ toxicity in the liver and kidney.

\section{MATERIALS AND METHODS}

Camel's milk samples: Daily milk samples were collected early in the morning from camel farm in the Abha area (Southeastern Saudi Arabia). Milk was collected from camels by hand milking as normally practiced by the farmers. The samples were collected in sterile screw bottles and kept in cool boxes until transported to the laboratory.
Chemicals: $\mathrm{AlCl}_{3}$ was purchased from Aldrich Chemical company (Milwaukee, WI, USA).

Determination of $\mathbf{A l C l}_{\mathbf{3}}$ daily dose: In 1989, the FAO/WHO Expert Committee on Food Additives reported that the daily intake of aluminum in children was between 2 and $6 \mathrm{mg}$, and in adults, it varied between 6 and $14 \mathrm{mg}^{[25-27]}$. Therefore, the daily intake of aluminum in an adult with a mean body weight $70 \mathrm{~kg}$ is between 0.1 and $0.2 \mathrm{mg} \mathrm{kg}^{-1}$ body weight. According to the guidelines published by the Drugs Institute ${ }^{[28]}$, established from animal studies, the dosage for rodents should be 4- to 10 -fold higher than a human dose. In our study, rats received a daily oral dose of $0.5 \mathrm{mg}$ $\mathrm{AlCl}_{3}\left[\mathrm{AlCl}_{3} \times 6 \mathrm{H}_{2} \mathrm{O}\right] / \mathrm{kg}$ of body weight. This dose was a 6 -fold excess over the minimum dose and 2.8fold over the maximum dose and, on average, 4-fold higher than the human dose.

Experimental design: White albino male rats (230-250 g) were supplied by the animal house at the medical school of King Khalid University. The rats were housed in standard plastic cages (10 rats/cage) in an environmentally controlled room with a constant temperature of $25-27^{\circ} \mathrm{C}$ and $12 \mathrm{~h}$ light/dark cycle. The rats were fed a "standard lab diet" and given ad libitum access to food and water. The Physiology Department committee of King Khalid University approved the design of the experiments, and the protocol follows their guidelines. Three groups of 10 rats were used for the experiments. All treatments were given, using a gavage needle, everyday for 30 days. The groups were treated as follows: Group 1, the Control group, received a daily dose of $1 \mathrm{~mL}$ normal saline; Group 2, the $\mathrm{AlCl}_{3}$ treated group, received $1 \mathrm{~mL}$ dose of a solution containing $0.5 \mathrm{mg} \mathrm{kg}^{-1}$ body weight of $\mathrm{AlCl}_{3}$ orally daily; Group 3, the Camel's milk- $\mathrm{AlCl}_{3}$ treated group, was treated daily with an oral dose of $1 \mathrm{~mL}$ camel's milk followed $10 \mathrm{~min}$ later by oral administration of $1 \mathrm{~mL} \mathrm{AlCl}_{3}\left(0.5 \mathrm{mg} \mathrm{kg}^{-1}\right)$ solution.

Collection of blood serum: At the end of day 30, the animals were subjected to over-night fasting before being sacrificed by cervical dislocation and blood samples were collected directly into tubes and were centrifuged at $3000 \mathrm{rpm}$ for $10 \mathrm{~min}$ to obtain serum.

Preparation of liver and kidney homogenate: The liver and kidney were quickly removed, washed in icecold, isotonic saline and blotted individually on ash-free filter paper. The tissues were then homogenized separately in $0.1 \mathrm{M}$ Tris- $\mathrm{HCl}$ buffer, $\mathrm{pH} 7.4$, using a Potter-Elvejham homogenizer at $4{ }^{\circ} \mathrm{C}$ and a diluting 
factor of four. The crude tissue homogenate was then centrifuged at $9,000 \mathrm{rpm}$ for $15 \mathrm{~min}$ in a cold centrifuge. The supernatant was collected and kept at$20^{\circ} \mathrm{C}$ until used for estimating lipid peroxidation, as determined by plasma concentration of thiobarbituric acid reactive substances (TBARS) and hydrogen peroxide (HP) levels, and the oxidative stress status, as measured by glutathione (GSH), superoxide dismutase (SOD) and catalase (CAT) activity.

Physiological and biochemical serum parameter analyses: Creatinine, urea, albumin, protein, bilirubin, cholesterol and triglyceride levels were evaluated as described previously by other groups $^{[29-34]}$. Additionally, aspartate aminotransferase (AST), alanine aminotransferase (ALT) and alkaline phosphatase (ALP) were assayed using commercial kits (Quimica Clinica Aplicada SA Spain). The activity of serum lactate dehydrogenase (LDH) was determined using the method described by Martinek ${ }^{[35]}$.

Estimation of lipid peroxidation and oxidative stress parameters in tissue homogenate:

Estimation of TBARS: The concentration of TBARS in the liver and kidney homogenate was determined using the method described by Okhawa ${ }^{[36]}$. In brief, the reaction mixture contained $0.1 \mathrm{~mL}$ tissue homogenate, $0.2 \mathrm{~mL}$ sodium dodecyl sulfate, $1.5 \mathrm{~mL}$ acetic acid and $1.5 \mathrm{~mL}$ aqueous solution of TBA. The $\mathrm{pH}$ of $20 \%$ acetic acid was pre-adjusted with $1 \mathrm{M} \mathrm{NaOH}$ to 3.5. The mixture was made up to $4 \mathrm{~mL}$ with distilled water and heated at $95^{\circ} \mathrm{C}$ for $1 \mathrm{~h}$, in a water bath. After cooling, $1 \mathrm{~mL}$ of distilled water and $5 \mathrm{~mL}$ of a mixture of $\mathrm{n}$ butanol and pyridine (15:1) were added and this was shaken vigorously using a vortex mixer. The absorbance of the upper organic layer was read at $532 \mathrm{~nm}$. The values were expressed as $\mathrm{mM} / 100 \mathrm{~g}$ of tissues.

Estimation of HP: The estimation of HP was done using the method described by Jiang ${ }^{[37]}$, in which 0.1 $\mathrm{mL}$ tissue homogenate (supernatant) was treated with $0.9 \mathrm{~mL}$ FOX reagent ( $88 \mathrm{mg}$ butylated hydroxytoluene, $7.6 \mathrm{mg}$ xylenol orange and $9.8 \mathrm{mg}$ ammonium iron sulfate added to $90 \mathrm{~mL}$ methanol and $10 \mathrm{~mL} 250 \mathrm{mM}$ sulfuric acid) and incubated at $37^{\circ} \mathrm{C}$ for $30 \mathrm{~min}$. The color development was read at $560 \mathrm{~nm}$. HP levels were expressed as $\mathrm{mM} / 100 \mathrm{~g}$ of tissues.

Estimation of GSH: The GSH content of the liver and kidney homogenate was measured at $412 \mathrm{~nm}$ using the method described by Sedlak and Lindsay ${ }^{[38]}$. The homogenate was precipitated with $50 \%$ trichloroacetic acid and then centrifuged at $1000 \mathrm{rpm}$ for $5 \mathrm{~min}$. The reaction mixture contained $0.5 \mathrm{~mL}$ of supernatant, $2.0 \mathrm{~mL}$ of Tris-EDT A buffer (0.2 M; pH 8.9) and $0.1 \mathrm{~mL}$ of $0.01 \mathrm{M} \mathrm{5.5}$ '-dithio-bis-2-nitrobenzoic acid. The solution was kept at room temperature for $5 \mathrm{~min}$ and then read at $412 \mathrm{~nm}$ on the spectrophotometer. The values were expressed as $\mathrm{mg} / 100 \mathrm{~g}$ of tissues.

Estimation of CAT activity: CAT activity was assayed using a commercially available Catalase Activity Assay Kit (Biovision, K773-100), according to the manufacture's instruction.

Estimation of SOD activity: The activity of hepatic SOD was assayed using a commercially available SOD Activity Assay Kit (Biovision, K335-100), according to the manufacture's instruction.

Statistical analysis: Data are given as the mean \pm SD. Student's t-test was used to determine if the difference observed among various treatment groups at individual time points was significant.

\section{RESULTS}

Oral administration of $\mathrm{AlCl}_{3}$ for 1 month resulted in statistically significant increases in urea, creatinine and bilirubin and decrease in both the total protein and albumin concentrations when compared to the serum from saline-treated rats (Table 1). However, the oral administration of camel's milk prior to treatment with $\mathrm{AlCl}_{3}$ maintained these parameters within normal levels.

Furthermore, the levels of cholesterol and triglycerides in the serum of $\mathrm{AlCl}_{3}$-treated were significantly higher than in the control-treated animals (Table 2). Administration of camel's milk prior to $\mathrm{AlCl}_{3}$ resulted in a highly significant reduction to near normal levels for serum lipid profiles when compared to $\mathrm{AlCl}_{3}$ treated rats (Table 2).

Evaluation serum levels of AST, ALT, ALP and LDH demonstrated that there was a highly significant increase in the activities of all enzymes in the serum of rats treated with $\mathrm{AlCl}_{3}$ compared to control rats, while rats treated with camel's milk and $\mathrm{AlCl}_{3}$ showed normal activities of these enzymes (Table 3 ). There was a significant increase in the TBARS and $\mathrm{HP}$ levels in the liver and kidneys of the $\mathrm{AlCl}_{3}$-treated rats (Table 4). In contrast, oral administration of camel's milk and $\mathrm{AlCl}_{3}$ resulted in normal levels. Additionally, the levels of enzymatic (SOD, CAT) and non-enzymatic (GSH) components of the oxidative system in the liver and the kidneys of experimental rats were also impacted by $\mathrm{AlCl}_{3}$ exposure. 
Am. J. Biochem. \& Biotech., 5 (3): 98-108, 2009

Table 1: Serum biochemistry of rats treated with $\mathrm{AlCl}_{3}$ or camel's milk $+\mathrm{AlCl}_{3}$

\begin{tabular}{lrcc}
\hline Parameter & \multicolumn{1}{c}{ Control } & \multicolumn{1}{c}{$\mathrm{AlCl}_{3}$} & Camel's milk $+\mathrm{AlCl}_{3}$ \\
\hline Total protein $\left(\mathrm{g} \mathrm{dL}^{-1}\right)$ & $6.24 \pm 0.450$ & $4.68 \pm 0.310^{*}$ & $7.20 \pm 0.36^{*}$ \\
Albumin $\left(\mathrm{g} \mathrm{dL}^{-1}\right)$ & $4.25 \pm 0.120$ & $3.20 \pm 0.168^{*}$ & $5.10 \pm 0.19^{*}$ \\
Urea $\left(\mathrm{mg} \mathrm{dL}^{-1}\right)$ & $31.60 \pm 3.110$ & $52.44 \pm 4.10^{*}$ & $31.70 \pm 3.65^{*}$ \\
Creatinine $\left(\mathrm{mg} \mathrm{dL}^{-1}\right)$ & $0.60 \pm 0.028$ & $1.34 \pm 0.132^{*}$ & $0.64 \pm 0.115^{*}$ \\
Bilirubin $\left(\mathrm{mg} \mathrm{dL}^{-1}\right)$ & $0.75 \pm 0.011$ & $1.62 \pm 0.069^{*}$ & $0.73 \pm 0.060^{*}$ \\
\hline Note: Values are given as mean $\pm \mathrm{SD}$ for groups of six animals each. \\
Values are statistically significant, *: p<0.05. $\mathrm{AlCl}_{3}$-treated rats were \\
compared with control rats; camel's milk + $\mathrm{AlCl}_{3}$-treated rats were \\
compared with $\mathrm{AlCl}_{3}$-treated rats
\end{tabular}

Table 2: Serum lipid profiles of rats treated with $\mathrm{AlCl}_{3}$ or camel's milk $+\mathrm{AlCl}_{3}$

\begin{tabular}{llll}
\hline Parameter $\left(\mathrm{mg} \mathrm{dL}^{-1}\right)$ & Control & $\mathrm{AlCl}_{3}$ & Camel's milk $+\mathrm{AlCl}_{3}$ \\
\hline Cholesterol & $148.0 \pm 4.9$ & $198.6 \pm 2.3 *$ & $150.0 \pm 2.4^{*}$ \\
Triglycerides & $91.7 \pm 3.3$ & $133.5 \pm 2.06^{*}$ & $91.8 \pm 1.09 *$ \\
\hline
\end{tabular}

Note: Values are given as mean \pm SD for groups of six animals each. Values are statistically significant, $*$ : $<<0.05 . \mathrm{AlCl}_{3}$-treated rats were compared with control rats; camel's milk $+\mathrm{AlCl}_{3}$-treated rats were compared with $\mathrm{AlCl}_{3}$-treated rats

Table 3: Changes in the activities of serum AST, ALT, ALP and LDH in rats treated with $\mathrm{AlCl}_{3}$ or camel's milk $+\mathrm{AlCl}_{3}$

\begin{tabular}{lccc}
\hline Parameter $\left(\mathrm{U} \mathrm{L}^{-1}\right)$ & \multicolumn{1}{c}{ Control } & \multicolumn{1}{c}{$\mathrm{AlCl}_{3}$} & Camel's milk $+\mathrm{AlCl}_{3}$ \\
\hline AST & $43.4 \pm 1.75$ & $67.40 \pm 1.37 *$ & $44.9 \pm 1.63^{*}$ \\
ALT & $27.0 \pm 1.79$ & $65.38 \pm 2.12^{*}$ & $29.9 \pm 2.09 *$ \\
ALP & $45.0 \pm 1.72$ & $78.90 \pm 2.03$ & $45.8 \pm 2.36^{*}$ \\
LDH & $734.2 \pm 38.1$ & $1160.80 \pm 33.7 *$ & $762.1 \pm 32.8^{*}$ \\
\hline
\end{tabular}

Note: Values are given as mean \pm SD for groups of six animals each. Values are statistically significant, $*: \mathrm{p}<0.05 . \mathrm{AlCl}_{3}$-treated rats were compared with control rats; camel's milk $+\mathrm{AlCl}_{3}$-treated rats were compared with $\mathrm{AlCl}_{3}$-treated rats

Table 4: Changes in the levels of TBARS, HP, GSH and the activity of CAT and SOD in the liver and kidney of rats treated with $\mathrm{AlCl}_{3}$ or camel's milk $+\mathrm{AlCl}_{3}$

\begin{tabular}{lrrr}
\hline Parameter & \multicolumn{1}{l}{ Control } & \multicolumn{1}{c}{$\mathrm{AlCl}_{3}$} & Camel's milk $+\mathrm{AlCl}_{3}$ \\
\hline Liver & & & \\
$\mathrm{TBARS}^{\mathrm{a}}$ & $0.87 \pm 0.058$ & $2.39 \pm 0.188^{*}$ & $0.88 \pm 0.080^{*}$ \\
$\mathrm{HP}^{\mathrm{b}}$ & $85.30 \pm 2.920$ & $119.20 \pm 4.890^{*}$ & $92.30 \pm 4.270^{*}$ \\
$\mathrm{GSH}^{\mathrm{c}}$ & $66.00 \pm 1.430$ & $19.40 \pm 0.910^{*}$ & $55.72 \pm 1.270^{*}$ \\
$\mathrm{CAT}^{\mathrm{d}}$ & $76.70 \pm 1.480$ & $47.80 \pm 1.200^{*}$ & $72.70 \pm 0.707^{*}$ \\
$\mathrm{SOD}^{\mathrm{e}}$ & $13.20 \pm 0.610$ & $8.50 \pm 0.370^{*}$ & $12.80 \pm 0.920^{*}$ \\
Kidney & & & \\
$\mathrm{TBARS}^{\mathrm{a}}$ & $0.66 \pm 0.040$ & $1.96 \pm 0.041^{*}$ & $0.70 \pm 0.024^{*}$ \\
$\mathrm{HP}^{\mathrm{b}}$ & $68.30 \pm 2.760$ & $117.20 \pm 2.220^{*}$ & $72.50 \pm 2.210^{*}$ \\
$\mathrm{GSH}^{\mathrm{c}}$ & $44.20 \pm 1.670$ & $30.20 \pm 0.560^{*}$ & $41.10 \pm 1.480^{*}$ \\
$\mathrm{CAT}^{\mathrm{d}}$ & $63.60 \pm 2.280$ & $41.80 \pm 1.070^{*}$ & $61.10 \pm 1.750^{*}$ \\
SOD $^{\mathrm{e}}$ & $7.12 \pm 0.096$ & $3.15 \pm 1.312^{*}$ & $6.80 \pm 0.379^{*}$ \\
\hline Note
\end{tabular}

Note: Values are given as mean \pm SD for groups of six animals each. Values are statistically significant, $*$ : $<<0.05 . \mathrm{AlCl}_{3}$-treated rats were compared with control rats; camel's milk $+\mathrm{AlCl}_{3}$-treated rats were compared with $\mathrm{AlCl}_{3}$-treated rats. ${ }^{\mathrm{a}} \mathrm{TBARS}, \mathrm{mM} / 100 \mathrm{~g}$ tissue; ${ }^{\mathrm{b}} \mathrm{HP}$, $\mathrm{mM} / 100 \mathrm{~g}$ tissue); ${ }^{\mathrm{c}} \mathrm{GSH}, \mathrm{mg} / 100 \mathrm{~g}$ protein; ${ }^{\mathrm{d}} \mathrm{CAT}, \mathrm{U} \mathrm{mg}{ }^{-1}$ protein; ${ }^{\mathrm{e}}$ : $\mathrm{SOD}, \mathrm{U} \mathrm{mg}^{-1}$ protein

In rats treated with $\mathrm{AlCl}_{3}$ alone, the activities of these proteins were decreased in comparison to the control group; while the oral administration of camel's milk prior to $\mathrm{AlCl}_{3}$ treatment resulted in a significant increase in SOD, CAT and GSH activity compared to the $\mathrm{AlCl}_{3}$-treated rats.

\section{DISCUSSION}

Aluminum is potentially toxic to humans and animals. It is present in many manufactured foods, medicines and, for purification purposes, it is also added to drinking water ${ }^{[39]}$. The present study investigated the protective effects of camel's milk against the harmful effects of $\mathrm{AlCl}_{3}$ on the liver and kidney of white albino rats through the analysis of multiple biochemical serum parameters, lipid peroxidation and oxidative stress in these organs.

Most studies examining the toxic effects of $\mathrm{AlCl}_{3}$ in animals have administered this compound intraperitoneally or parenterally, which does not represent the main route of human exposure ${ }^{[40]}$. Aluminum enters the body via two major routes: pulmonary and oral. Although only a small portion of aluminum is absorbed through the gastrointestinal tract, oral intake is associated with the greatest toxicological implications ${ }^{[40]}$. For this reason, our current study evaluated orally administered $\mathrm{AlCl}_{3}$.

It has been reported that animals exposed to $\mathrm{AlCl}_{3}$ displayed hepatic necrosis, which was indicated by an increase in serum levels of liver-specific enzymes including AST and ALT ${ }^{[41-43]}$. This was attributed to the DNA and/or RNA binding potential of aluminum, which may inhibit the function of important enzymes, such as hexokinase, acids, alkalines, phosphatases and phosphodiesterases $^{[44]}$. In our study, liver damage was addressed through biochemical assays. Four separate liver enzymes, including AST and ALT, which, together, are known as transaminases, ALP, which is a cholestatic liver enzyme, and $\mathrm{LDH}$, are reliable indicators of liver function. AST and ALT are critical enzymes for biological processes ${ }^{[25]}$. An increase in serum AST and ALT in rats treated with $\mathrm{AlCl}_{3}$ was in agreement with previous findings demonstrating that $\mathrm{AlCl}_{3}$ exposure promoted liver necrosis $\left[{ }^{39,41,42]}\right.$. AST is released in to the plasma from the injured hepatic cells. Also, an elevated serum level of ALT is indicative of liver disease, as this enzyme is present in large quantities in the liver and increases in the serum following hepatocellular degeneration or destruction. Therefore, increases in the serum level of these enzymes suggests liver damage and alterations in liver function. Because it is a membrane-bound enzyme related to the transport of various metabolites, ALP is a sensitive biomarker of liver disease $\left[{ }^{45}\right.$. Its activity is 
dependent on energy metabolism and processes in the body and a decrease in its activity may indicate impaired cellular energy processing ${ }^{[46]}$. $\mathrm{AlCl}_{3}$-induced increases in ALP activity is in agreement with published results ${ }^{[44,47]}$. Also, El-Demerdash ${ }^{[39]}$ reported that, in mice fed wheat containing an aluminum residue, the activity of these enzymes was also increased Additionally, the aluminum-induced increase in the ALP may also be due to increased osteoblastic activity, which disrupts bone formation ${ }^{[47]}$.

$\mathrm{LDH}$ is another index of hepatotoxicity. In the serum of $\mathrm{AlCl}_{3}$-treated rats, there was a significant increase in the $\mathrm{LDH}$ level compared to rats given normal saline, which is in agreement with published findings demonstrating that, in rats, hepatic damage by drugs and chemical substances is characterized by increased serum $\mathrm{LDH}^{[48-50]}$. The increase in total bilirubin in the serum of $\mathrm{AlCl}_{3}$-treated rats may be the result of decreased liver uptake (conjugation) or increased production from hemolysis ${ }^{[51]}$. Our results demonstrated that oral administration of $\mathrm{AlCl}_{3}$ caused a significant increase in serum cholesterol and triglycerides, which may indicate a loss of membrane integrity, disturbance of lipid metabolism and/or liver dysfunction ${ }^{[52]}$.

With regards to renal damage, biochemical findings in this study are in agreement with other studies $^{[11,14,47,53]}$ demonstrating that the oral administration of $\mathrm{AlCl}_{3}$ resulted in a significant increase in serum urea and creatinine and a substantial decrease in total protein and albumin levels compared to control animals. Collectively, these findings demonstrate that accumulation of aluminum in the kidneys may promote degeneration of renal tubular cells leading to nephrotoxicity ${ }^{[11,14]}$. Szilagyi et al ${ }^{[47]}$ reported that alterations in serum urea may be related to metabolic disturbances secondary to renal dysfunction. Alternatively, Katyal et al. ${ }^{[53]}$ published that the increase in urea serum concentration in aluminumtreated animals may be due to aluminum-mediated changes in liver function; urea is the end product of protein catabolism. Albumin is the most abundant protein in human plasma, representing $55-65 \%$ of the total protein. Rate at which albumin is synthesized in the liver depends on protein intake, which is regulated by the plasma albumin level. Most of the albumin filtered through the kidney glomeruli is reabsorbed by proximal tubule cells where lysosomal enzymes degrade the albumin into fragments that are returned to the circulation. The observed decrease in albumin in aluminum-treated rats may be due to changes in protein synthesis and/or metabolism in the liver ${ }^{[42]}$. Furthermore, aluminum may promote proteinuria by causing a nephritic syndrome or chronic glomerulonephritis.

It has also been suggested that the toxic effects associated with aluminum are due to the generation of Reactive Oxygen Species (ROS) ${ }^{[39]}$, which results in the oxidative deterioration of cellular lipids, proteins and $\mathrm{DNA}^{[39,54]}$. Therefore, aluminum toxicity appears to be mediated, in part, by free-radical generation ${ }^{[55,56]}$. A recent study demonstrated that aluminum may alter the activity of a number of tissue antioxidative enzymes, such as xanthine oxidase, GSH, SOD ${ }^{[55]}$. Our data support this hypothesis; both TBARS and HP levels were found to be elevated in $\mathrm{AlCl}_{3}$-treated rats while GSH, SOD and CAT activity were decreased in the liver and kidney. These observations are similar to previously published findings demonstrating that aluminum intake promoted oxidative stress $^{[57-60]}$. Although aluminum is not a transition metal, and therefore, cannot initiate peroxidation, many studies have searched for a correlation between aluminum accumulation and oxidative damage in tissues ${ }^{[60-62]}$. An in vitro study indicated that aluminum greatly accelerates iron-mediated lipid peroxidation ${ }^{[62]}$. Another study reported that exposure to aluminum could promote disruptions in the mineral balance, resulting in aluminum ions replacing iron and magnesium, which would then lead to a reduction in $\mathrm{Fe}^{2+}$ binding to ferritin $^{[63]}$. Free iron ions released from biological complexes by aluminum can catalyze HP decomposition to hydroxyl radicals via Fenton's reaction $^{[63]}$. This high hydroxyl radical reactivity could initiate the peroxidation of membrane lipids, causing membrane damage. The primary effects of aluminum on the liver and kidney functions are thought to be mediated via damage to cell membranes. Lipid peroxidation of biological membranes leads to a loss of membrane fluidity, changes in membrane potential, an increase in membrane permeability and alterations in receptor functions ${ }^{[60]}$. In the present report, we observed a significant increase in lipid peroxidation after $\mathrm{AlCl}_{3}$ exposure, as measured in terms of TBARS and HP levels in the liver and kidney of the rats. These result are in agreement with many studies that also demonstrated a significant increase in TBARS and HP in the kidney, liver and the brain of rats after intoxication by aluminum salts ${ }^{[53,60,63,64]}$. The increased lipid peroxidation is due to inhibition or a change in the activity of non-enzymatic and enzymatic components of the oxidative system, i.e., GSH, SOD and CAT, in the 
liver and kidney. The glutathione peroxidase system consists of several components, one of which is $\mathrm{GSH}^{[65]}$. GSH, an essential component of oxidative system, serves as a cofactor for glutathione transferase, which helps to remove certain drugs and chemicals, as well as other reactive molecules, from the cells ${ }^{[65]}$. Moreover, GSH can interact directly with certain ROS, i.e, hydroxyl radicals, to detoxify them, as well as performing other critical activities in the cell. Thus, GSH is probably the most important antioxidant present in cells ${ }^{[65]}$. The enzymatic antioxidant defense system, which includes SODs and CATs, can decompose superoxide and hydrogen peroxide in the cells and are the main defense against oxidative injuries. SOD catalyzes the rapid removal of superoxide radicals, generating $\mathrm{H}_{2} \mathrm{O}_{2}$. Therefore, SOD works in collaboration with $\mathrm{H}_{2} \mathrm{O}_{2}$ removing enzymes. CAT is present in the peroxisomes of nearly all aerobic cells and functions to protect the cell from the toxic effects of hydrogen peroxide through catalyzing its decomposition into molecular oxygen and water without the production of free radicals. In the present study, $\mathrm{AlCl}_{3}$ exposure induced free radicals and it may inhibit the enzymes involved in antioxidant defense, specifically, SOD and CAT. We observed a significant decrease in these enzymes in the kidney and liver of treated rats. Our results are in agreement with Nehru and Anand ${ }^{[60]}$ who observed a significant decrease in SOD and CAT activity in the brain after aluminum treatment. The decrease in both enzyme activities could be the result of reduced synthesis of these enzymes due to higher intracellular concentrations of aluminum or accumulation of free radicals ${ }^{[60]}$. Also Orihuela et al. ${ }^{[66]}$ reported that, at high doses, aluminum is capable of inducing free radicals and decreasing the levels of GSH. Aluminum might also affect GSH synthesis by decreasing glutathione-synthase activity, which would result in reduced GSH levels.

Our results demonstrated that treatment with camel's milk prior to $\mathrm{AlCl}_{3}$ alleviates $\mathrm{AlCl}_{3}$-associated hazards and protects the kidneys and liver from $\mathrm{AlCl}_{3}$ toxicity. The protective effect of camel's milk could be attributed to its antioxidant activity and it may possibly have chelating effects on aluminum. It has been reported that camel's milk contains high levels of vitamins $\mathrm{A}, \mathrm{B} 2, \mathrm{C}$ and $\mathrm{E}$ and is very rich in magnesium $(\mathrm{Mg})$ and other trace elements ${ }^{[21]}$. These vitamins are antioxidants that have been found to be useful in preventing tissue injury caused by toxic agents. $\mathrm{Mg}$ protects cells from heavy metals such as aluminum, mercury, lead, cadmium, beryllium and nickel, which explains why re-mineralization is so essential for heavy metal detoxification and chelating. In fact, $\mathrm{Mg}$ deficiency has been associated with production of $\mathrm{ROS}^{[67]}$. Additionally, $\mathrm{Mg}$ protects cells against oxyradical damage and assists in the absorption and metabolism of vitamins $\mathrm{B}, \mathrm{C}$ and $\mathrm{E}^{[68]}$, which are antioxidants important in cellular protection. Recent evidence suggests that vitamin $\mathrm{E}$ enhances glutathione levels and may play a protective role in $\mathrm{Mg}$ deficiencyinduced cardiac lesions ${ }^{[68]}$. Also, it has been reported that $\mathrm{Mg}$ is essential for biosynthesis of glutathione because the enzyme, glutathione synthetase, requires $\gamma$ glutamyl cysteine, glycine, ATP and Mg ions to form glutathione $^{[69]}$.

Additionally, camel's milk is rich in zinc $(\mathrm{Zn})^{[21]}$, which is a trace element essential for living organisms. More then 300 enzymes require $\mathrm{Zn}$ for their activity. It also plays an important role in DNA replication, transcription and protein synthesis, influencing cell division and differentiation ${ }^{[70]}$. It has been noted that $\mathrm{Zn}$ has a relationship with many enzymes in the body and can prevent cell damage through activation of the antioxidant system ${ }^{[71-73]}$. Zinc is an essential component of the oxidant defense system and functions at many levels $^{[74]}$. One study has shown that a diet deficient in $\mathrm{Zn}$ paves the way for cell damage in the rat testis ${ }^{[75]}$. Furthermore, Zn deficiency increases lipid peroxidation in various rat tissues, whereas the $\mathrm{Zn}$ supplementation corrects this increase ${ }^{[72,73,76]}$. Interestingly, a protective effect of $\mathrm{Zn}$ has been reported in vitro against cadmium toxicity. This is probably due to induction of oxidative stress and apoptosis ${ }^{[77,78]}$.

Our study demonstrated that treatment of rats with camel's milk prior to $\mathrm{AlCl}_{3}$ resulted in decreased cholesterol and triglyceride levels in the serum compared to the $\mathrm{AlCl}_{3}$-intoxicated group. It can be concluded that camel's milk can act in several ways to lower serum cholesterol and triglycerides. First, uptake of cholesterol and triglycerides in the gastrointestinal tract could be inhibited; second, LDL-cholesterol could be eliminated from the blood via the LDL receptor; and finally, the activity of cholesterol-degrading enzymes could be increased.

Another interpretation for the improvement of the evaluated parameters in the present investigation may be due to a decrease in aluminum accumulation in the liver and kidneys in the rats given camel's milk. The possible mechanisms include camel's milk-mediated reduction of the renal uptake of aluminum by competition for a common transporter, which would result in protective activity against aluminum-mediated damage to hepatocytes and renal function. Previously, 
we reported that camel's milk alleviates alterations in biochemical parameters and oxidative stress produced in the liver of rats treated with cadmium chloride ${ }^{[79]}$, which correlates with our current findings.

\section{CONCLUSION}

Aluminum has adverse effects on human health. Our results demonstrate that $\mathrm{AlCl}_{3}$ is capable of inducing marked alterations in biochemical parameters and oxidative damage, and inhibiting the function of antioxidant enzymes. Consequently, attention should be paid to the sources of aluminum in food, water and medical drugs. Camel's milk, administered before $\mathrm{AlCl}_{3}$ exposure, minimized $\mathrm{AlCl}_{3}$-associated hazards. Therefore, drinking camel's milk could be beneficial for alleviating aluminum toxicity. Further studies are required, using a human population, to confirm these protective effects.

\section{ACKNOWLEDGEMENT}

The researcher wishes to thank Mr. Mahmoud Alkhateeb and Mr. Mohammed Abbas (King Khalid University, College of Medicine) for their help in experimental design and performing the biochemical analysis.

\section{REFERENCES}

1. Sigel, H. and A.E. Sigel, 1988. Metal ions in dialysis demenia syndrome and aluminum intoxication. Nephron, 31: 1-10.

2. Farina, M., L.N. Rotta, F.A. Soares, F. Jardim, R. Jacques, D.O. Souza and J.B. Rocha, 2002. Effects of aluminum sulfate on erythropoiesis in rats. Toxicol Lett 132: 131-139. http://www.ncbi.nlm.nih.gov/pubmed/12044547

3. Lin, J.L., Y.J. Yang, S.S. Yang and M.L. Leu, 1997. Aluminum utensile contribute to aluminum accumulation in patients with renal disease. Am. J. Kidney Dis., 30: 653-58. http://cat.inist.fr/?aModele=afficheN\&cpsidt=2081759

4. Sharma, P. and K. Mishra, 2006. Amelioration of fumonisin B1 hepatotoxicity in mice by depletion of $\mathrm{T}$ cells with anti-Thy-1.2. Reprod. Toxicol., 21: 313-321.

http://www.ncbi.nlm.nih.gov/pubmed/16690192

5. Osinska, E., D. Kanoniuk and A. Kusiak, 2004. Aluminum hemotoxicity mechanisms. Ann. Univ. Mariae Curie Sklodowska Med., 59: 411-416. http://www.ncbi.nlm.nih.gov/pubmed/16146022
6. Yokel, R.A. and P.J. McNamara, 2001. Aluminum toxicokinetics: An updated minireview. Pharmacol. Toxicol., $\quad$ 88: 159-167. http://www.ncbi.nlm.nih.gov/pubmed/11322172

7. Abbasali, K.M., T. Zhila and N. Farshad, 2005. Developmental toxicity of Aluminum from high doses of $\mathrm{AlCl}_{3}$ in mice. J. Applied Res., 5: 575-579. http://jrnlappliedresearch.com/articles/Vol5Iss4/02 Karimpour.pdf

8. Cannata, J., J. Briggs, R. Junor and S. Fell, 1983. Aluminum hydroxide intake real risk of aluminum toxicity. Br. Med. J., 286: 1937-1938. http://www.pubmedcentral.nih.gov/articlerender.fc gi?artid= 1548249

9. Kaehny, W., A. Hegg and A. Alfrey, 1997. Gastrointestinal absorption of Aluminum from Aluminum containing antacids. N. Engl. J. Med., 296: 1389-1390.

http://content.nejm.org/cgi/content/citation/296/24/ 1389

10. Lione, A., 1985. Aluminum toxicity and the Aluminum containing medication. J. Pharmacol. Ther., 29: 255-285. http://cat.inist.fr/?aModele=afficheN\&cpsidt=7862878

11. Kloppel, H., A. Fliedner and W. Kordel, 1997. Behavior and endotoxicology of Aluminum in soil and water. Rev. Sci. Literature Chemosphere, 35: 353-363. http://www.ncbi.nlm.nih.gov/sites/entrez

12. Shehla, K.F., P.A. Prabhavathi, P. Padmavathi and P.P. Reddy, 2001. Analysis of chromosomal aberrations in men occupationally exposed to cement dust. Mutat. Res., 490: 179-186. http://cat.inist.fr/?aModele=afficheN\&cpsidt=913452

13. Agency for Toxic Substances and Disease Registry, 2008. Toxicological profile for Aluminum. US Department of Health and Human Services. Public Health Service, pp: 1-8. http://www.atsdr.cdc.gov

14. Alfrey, A.C., G.R. LeGendre and W.D. Kaehny, 1976. The dialysis encephalopathy syndrome. Possible aluminum intoxication. N. Engl. J. Med., 294: 184-188.

http://content.nejm.org/cgi/content/abstract/294/4/184

15. Klein, G.L., 1993. Aluminum and hepatobiliary complications of total parenteral nutrition. Gastroenterology, $\quad 10$ : 1583-1584. http://www.ncbi.nlm.nih.gov/pubmed/8343199

16. Ward, M.K., T.G. Feest, H.A. Ellis, I.S. Parkinson and D.N. Kerr, 1978. Osteomalacic dialysis osteodystrophy: Evidence for a water-borne aetiological agent, probably Aluminum. Lancet, 22: 841-845.

http://www.ncbi.nlm.nih.gov/pubmed/76795 
17. Short, A.I.K., R.J. Winney and J.S. Robson, 1980. Robson, Reversible microcytic hypochromic anaemia in dialysis patients due to Aluminum intoxication. Proc. Eur. Dial. Transplant. Assoc., 17: 226-233.

http://www.ncbi.nlm.nih.gov/pubmed/7243773

18. Gupta, V.B., G. Anitha, M.L. Hegda, L. Zecca and R.M. Garruto et al., 2005. Aluminum in Alzheimer's disease: Are we still at a crossroad? Cell. Mol. Life Sci., 62: 143-158. http://www.ncbi.nlm.nih.gov/pubmed/15666086

19. Campbell, A., 2002. The potential role of Aluminum in Alzheimer's disease. Nephrol. Dial. Transplant., $\quad$ 17: $17-20$. http://www.ncbi.nlm.nih.gov/pubmed/11904353

20. Flaten, T., 2001. Aluminum as a risk factor in Alzheimer's disease, with emphasis on drinking water. Brain Res. Bull., 55: 187-196. http://www.ncbi.nlm.nih.gov/pubmed/11470314

21. Knoess, K.H., 1979. Milk production of the dromedary. Proceeding of the IFS Symposium Camels, Sudan, pp: 201-214.

22. Rao, M.B., R.C. Gupta and N.N. Dastur, 1970. Camels' milk and milk products. Ind. J. Dairy Sci., 23: 71-78.

23. Mal, G., D.S. Sena, V.K. Jain and M.S. Sahani, 2001. Therapeutic utility of camel milk as nutritional supplement in chronic pulmonary tuberculosis. Livestock Int., 2001: 4-8.

24. Agrawal, R.P., S.C. Swami, R. Beniwal, D.K. Kochar and R.P. Kothari, 2002. Effect of Camel milk on glycemic control, risk factors and diabetes quality of life in Type-1 diabetes: A randomised prospective controlled study. Int. J. Diabetes Develop. Countries, 22: 70-74. http://www.ijddc.com/article.asp?issn=09733930 ; year $=2002$; volume $=22 ;$ issue $=2 ;$ spage $=70$; epa ge=74; aulast $=$ Agrawal

25. Gramiccioni, L., G. Ingrao, M.R. Milana, P. Santaroni and G. Tomassi, 1996. Aluminum levels in Italian diets and in selected foods from Aluminum utensils. Food. Addit. Contam., 13: 767-774. http://www.ncbi.nlm.nih.gov/pubmed/8885317

26. Starska, K., 1993. Aluminum in food. Rocz. Państw. Zakł. Hig., 44: 55-63. http://www.ncbi.nlm.nih.gov/pubmed/8235343

27. Sepe, A., S. Costantini, L. Ciaralli, M. Ciprotti and R. Giordano, 2001. Evaluation of Aluminum concentrations in samples of chocolate and beverages by electrothermal atomic absorption spectrometry. Food. Addit. Contam., 18: 788-196. http://www.ncbi.nlm.nih.gov/pubmed/11552746
28. Biruletyn Informacyiny Instytutu Lekw. Numer Specjalny 3, 1988.

29. Henry, R.J., D.C Cannon and W. Winkelman, 1974. Clinical Chemistry Principals and Techniques. 11th Edn., Happer and Row Publishers, pp: 1629.

30. Natelson, S., 1957. Microtechniques of Clinical Chemistry for the Routine Laboratory. Publisher, Springfield, Illinois, pp: 381.

31. Reinhold, J., 1980. Determination of Serum Total Protein, Albumin and Globulin Fractions by the Biuret Method. In: Practical Clinical Biochemistry, Varley, H., A.H. Gowen Lock and M. Bell (Eds.)., Vol. I, 5th Edn., William Heinemann, London, pp: 45-47.

32. Lowry, O.H., N.J. Rosenbrough, A.L. Farr and R.L. Randall, 1951. Protein measurement with the Folin phenol reagent. J. Biol. Chem., 193: 264-275. http://www.ncbi.nlm.nih.gov/pubmed/14907713

33. Pearlman, F.C. and R.T.Y. Lee, 1974. Detection and measurement of total bilirubin in serum, with use of surfactants as solubilizing agents. Clin. Chem., $\quad 20$ : 447-453. http://www.ncbi.nlm.nih.gov/pubmed/4818198

34. Carr, T., C.J. Andressen and L.L. Rudel, 1993. Enzymatic determination of triglyceride, free cholesterol and total cholesterol in tissue lipid extracts. Clin. Chem., 26: 39-42. http://www.ncbi.nlm.nih.gov/pubmed/8448837

35. Martinek, R.G., 1972. A rapid ultraviolet spectrophotometric lactic dehydrogenase assay. Clin. Chem. Acta, 40: 91-99. http://www.ncbi.nlm.nih.gov/pubmed/4341434

36. Okhawa, H., N. Ohigni and K. Yagi, 1979. Assay of lipid peroxides in animal tissues by thiobarbituric acid reaction. Anal. Biochem., 95: 351-358. http://www.ncbi.nlm.nih.gov/pubmed/36810

37. Jiang, Z.Y., J.V. Hunt and S.D. Wolff. 1992. Ferrous ion oxidation in the presence of xylenol orange for detection of lipid hydroperoxides in low density lipoprotein. Anal. Biochem., 202: 384-391. http://www.ncbi.nlm.nih.gov/pubmed/1519766

38. Sedlak, J. and R.H. Lindsay, 1968. Estimation of total protein bound and non-protein sulfhydryl groups in tissue with Ellmans reagent. Anal. Biochem., 25: 293-98. http://www.ncbi.nlm.nih.gov/pubmed/4973948

39. El-Demerdash, F.M., M.I. Yousef, F.S. Kedwany and H.H. Baghdadi, 2004. Role of $\alpha$-tocopherol and $\beta$-carotene in ameliorating the fenvalerateinduced changes in oxidative stress, hematobiochemical parameters and semen quality of male rats. J. Environ. Sci. Health Bull., 39: 443-459. http://cat.inist.fr/?aModele $=$ afficheN\&cpsidt $=15760824$ 
40. Testolin, G., D. Erba, D. Ciappellano and G. Bermano, 1996. Influence of organic acids on aluminum absorption and storage in rat tissues. Food Addit. Contam.,13:21-27. http://www.ncbi.nlm.nih.gov/pubmed/8647304

41. Hassoun, E.A. and S.J. Stohs, 1995. Comparative studies on oxidative stress as a mechanism for the fetotoxic of TCDD endrin and lindane in C57BL/6J and DBA/2J mice. Teratology, 51: 186. http://www.ncbi.nlm.nih.gov/sites/entrez

42. Chinoy, N.J. and M.R. Memon, 2001. Beneficial effects of some vitamins and Calcium on fluoride and Aluminum toxicity on gastrocnemius muscle and liver of male mice. Fluoride, 34: 21-33. http://www.fluoride-journal.com/01-34-1/34121.pdf

43. El-Demerdash, F.M., 2004. Antioxidant effect of vitamin $\mathrm{E}$ and selenium on lipid peroxidation, enzyme activities and biochemical parameters in rats exposed to Aluminum. J. Trace Elements Med. Biol., 18: 113-122.

http://www.ncbi.nlm.nih.gov/pubmed/15487771

44. Ochmanski, W. and W. Barabasz, 2000. Aluminum occurrence and toxicity for organisms. Przegl. Lek., 57: 665-668. http://www.ncbi.nlm.nih.gov/pubmed/11293216

45. Lakshmi, R., R. Kundu, E. Thomas and A.P. Mansuri, 1991. Mercuric chloride induced inhibation of acid and alkaline phosphatase activity in the kidney of Mudskipper; Boleophthalmus dentatus. Acta Hydrochim Hydrobiol., 3: 341-344. DOI: 10.1002/aheh.19910190314

46. Shakoori, A.R., U. Butt, R. Riffat and F. Aziz, 1994. Hematological and biochemical effects of danitol administered for two months on the blood and liver of rabbits. Zeitschrift Fuer Angewandte Zoologie 80: 165-180. http://direct.bl.uk/bld/PlaceOrder.do?UIN=026728 101\&ETOC $=$ EN\&from $=$ searchengine

47. Szilagyi, M., J. Bokori, S. Fekete, F. Vetesi, M. Albert and I. Kadar, 1994. Effects of long-term aluminum exposure on certain serum constituents in broiler chickens. Eur. J. Clin. Chem. Clin. Biochem., 32: 485-486. http://cat.inist.fr/?aModele $=$ afficheN\&cpsidt $=4275068$

48. Shibayna, Y., 1992. Hepatotoxicity of heated and oxygenated corn oil. Exp. Toxicol. Pathol., 44: $255-258$.

http://cat.inist.fr/?aModele=afficheN\&cpsidt $=4594664$
49. Xia, L. and T. Yu, 1992. Study of the relationship between the hepatotoxicity and free radical induced by trichloroethaone in rat. Biomed. Environ. Sci., 5: 303-313.

50. Pispirigos, S.K., P. Catsoulakos and G. Karakiulakis, 1993. Evaluation of kidney and liver substance toxicity of anti-tumer agents using serum biochemical parameters in rats. Biochem. Mol. Biol. Int., 31: 565-578. http://www.ncbi.nlm.nih.gov/pubmed/7906982

51. Rana, S.V., S. Rekha and V. Seema, 1996. Protective effects of few antioxidants on liver function in rats treated with cadmium and mercury. Indian J. Exp. Biol., 34: 177-179. http://www.ncbi.nlm.nih.gov/pubmed/8641719

52. Sarin, S., V. Gupta and K.D. Gill, 1997. Alterations in lipid composition and neuronal injury in primates following chronic Aluminum exposure. Biol. Trace Elem. Res., 59: 133-143. http://www.ncbi.nlm.nih.gov/pubmed/9522055

53. Katyal, R., B. Desigan, C.P. Sodhi and S. Ojha, 1997. Oral aluminum administration and oxidative injury. Biol. Trace Elem. Res., 57: 125-130. http://cat.inist.fr/?aModele $=$ afficheN\&cpsidt $=1082$ 5234

54. Mansour, S., S. Alan and B.R. Norman, 2006. Aluminum-induced injury to kidney proximal effects on markers of oxidative damage. J. Trace Elem. Med. Biol., 19: 267-273. http://www.ncbi.nlm.nih.gov/pubmed/16443175

55. Moumen, R., N. Ait-Oukhatar, F. Bureau, C. Fleury, D. Bougle and P. Arhan, 2001. Aluminum increases xanthine oxidase activity and disturbs antioxidant status in the rat. J. Trace Elem. Med. Biol., 15: 89-93. http://www.ncbi.nlm.nih.gov/pubmed/11787993

56. Anane, R. and E.E. Creppy, 2001. Lipid peroxidation as a pathway to Aluminum cytotoxicity in human skin fibroblast cultures: Prevention by superoxide dismutase plus catalase and vitamins E and C. Hum. Exp. Toxicol., 20: 477-481. http://www.ncbi.nlm.nih.gov/pubmed/11776410

57. Yousef, M.I., 2004. Aluminum-induced changes in hemato-biochemical parameters, lipid per oxidation and enzyme activities of male rabbits: Protective role of ascorbic acid. Toxicology, 199: 47-57. http://cat.inist.fr/?aModele $=$ afficheN\&cpsidt $=1573$ 0717 
58. Yousef, M.I., A.M.A. El-Morsy and M.E. Hassan, 2005. Aluminum-induced deterioration in reproductive performance and seminal plasma biochemistry of male rabbits: Protective role of ascorbic acid. Toxicology, 215: 97-107. http://cat.inist.fr/?aModele $=$ afficheN\&cpsidt $=1720$ 4552

59. Yousef, M.I., I.K. Kamel, I.E. El-Guendi and F.M. El-Demerdash, 2007. An in vitro study on reproductive toxicity of Aluminum chloride on rabbit sperm: the protective role of some antioxidants. Toxicology, 239: 213-223. http://www.ncbi.nlm.nih.gov/pubmed/17714845

60. Nehru, B. and P. Anand, 2005. Oxidative damage following chronic Aluminum exposure in adult and pup rat brains. J. Trace Elem. Med. Biol., 19: 203208.

http://www.ncbi.nlm.nih.gov/pubmed/16325537

61. Cherroret, G., B. Capolaghi, M.F. Hutin, D. Burnel, D. Desor and P.R. Lehr, 1995. Effects of postnatal aluminum exposure on biological parameters in the rat plasma. Toxicol. Lett., 78: 119-125. http://cat.inist.fr/?aModele $=$ afficheN\&cpsidt $=3567$ 815

62. Wilhelm, M., D.E. Jaeger, H. Schull-Cablitz, D. Hafner and H. Idel, 1996. Hepatic clearance and retention of Aluminum: Studies in the isolated per fused rat liver. Toxicol. Lett., 89: 257-263. http://www.ncbi.nlm.nih.gov/pubmed/9001595

63. Ward, R.J., Y. Zhang and R.R. Crichton, 2001. Aluminum toxicity and iron homeostasis. J. Inorg. Biochem., $\quad$ 87: 9-14. http://www.ncbi.nlm.nih.gov/pubmed/11709207

64. Fraga, C.G., P.I. Oteiza, M.S. Golub, M.E. Gershwin and C.L. Keen, 1990. Effects of Aluminum treated on brain lipid peroxidation. Toxicol. Lett., 51: 213219. http://www.ncbi.nlm.nih.gov/pubmed/2330606

65. Wu, D. and I. Cederbaum, 2003. Alcohol, oxidative stress and free radical damage. Alcohol Res. Health, 27: 277-284. http://pubs.niaaa.nih.gov/publications/arh27-4/277284.htm

66. Orihuela, D., V. Meichtry, N. Pregi and M. Pizarro, 2005. Short-term oral exposure to Aluminum decreases glutathione intestinal levels and changes enzyme activities involved in its metabolism. J. Inorg. $\quad$ Biochem., 99: 1871-1878. http://www.ncbi.nlm.nih.gov/pubmed/16084594
67. Martin, H., L. Richert and A. Berthelot, 2003. Magnesium deficiency induces apoptosis in primary cultures of rat hepatocytes. Am. Soc. Nutr. Sci. J. Nutr., 133: 2505-2511. http://jn.nutrition.org/cgi/content/full/133/8/2505

68. Barbagallo, M., 1999. Effects of vitamin $\mathrm{E}$ and glutathione on glucose metabolism: Role of magnesium. Hypertension, 34: 1002-1006. http://www.ncbi.nlm.nih.gov/pubmed/10523398

69. Virginia, M., M.B. Smith, M.J. Brauner and W.P. Majerus, 1971. Glutathione synthesis in human erythrocytes. J. Clin. Invest., 50: 507-513. http://www.pubmedcentral.nih.gov/articlerender.fc gi? artid=442063

70. Frederickson, C.J., 1989. Neurobiology of zinc and zinc containing neurons. Int. Rev. Neurobiol., 31:145-238. http://www.ncbi.nlm.nih.gov/pubmed/2689380

71. Powell, S.R., 2000. Antioxidant properties of zinc. J. $\quad$ Nutr., 130 : 1447-1454. http://jn.nutrition.org/cgi/content/abstract/130/5/14 $47 \mathrm{~S}$

72. Ozturk, A., A.K. Baltaci, R. Mogulkoc, E. Oztekin, A. Sivrikaya, E. Kurtogh and A. Kul, 2003. Effects of zinc deficiency and supplementation on malondialdehyde and glutathione levels in blood and tissue of rats performing swimming exercise. Biol. Trace Elem. Res., 96: 227-236. http://www.ncbi.nlm.nih.gov/pubmed/14716102

73. Ozdemir, G. and F. Inanc, 2005. Zinc may protect remote ocular injury caused by intestinal ischemia reperfusion in rats. Tohoku J. Exp. Med., 206: 247-251. http://www.sasappa.co.jp/online/abstract/tmp/1/206 /html/0112060310.html

74. Sato, M. and I. Bremner, 1993. Oxygen free radicals and metalothionein. Free Radic. Biol. Med., 14: 325-327. http://www.ncbi.nlm.nih.gov/pubmed/8458590

75. Cai, Y.Q., H. Teranishi, K. Aoshima, T. Katoh, Y. Arai and N. Kasuya, 2001. Development of the fluorometric ELISA method for determination of alpha (1)-microglobulinuria in cadmium-polluted area in Japan. Int. Arch. Occup. Environ. Health, 7: 514-518.

http://direct.bl.uk/bld/PlaceOrder.do?UIN=103087 053\&ETOC $=$ RN\& from $=$ searchengine

76. Shaheen, A.A. and A.A. El-Fattah, 1995. Effect of dietary zinc on lipid peroxidation, glutathione, protein levels and superoxide dismutase activity in rat tissues. Int. J. Biochem. Cell. Biol., 27: 89-95. http://www.ncbi.nlm.nih.gov/pubmed/7757885 
77. Bray, T.M. and W.J. Bettger, 1990. The physiological role of zinc as an antioxidant. Free Radic. Biol. Med., 8: 281-91. http://www.ncbi.nlm.nih.gov/pubmed/2187766

78. Goering, P.L. and C.D. Klaassen, 1984. Zincinduced tolerance to cadmium hepatotoxicity Toxicol. Applied Pharmacol., 74: 299-307. http://www.ncbi.nlm.nih.gov/pubmed/6740679
79. AL-Hashem, F., M. Dallak, N. Bashir, M. Abbas, R. Elessa, M. Khalil and M. Alkhateeb, 2009. Camel's Milk protects against cadmium chloride induced toxicity in white albino rats. Am. J. Pharm. Toxicol., 4: 107-111. http://www.scipub.org/fulltext/AJPT/AJPT43107117.pdf 